\title{
STUDI TRANSPOR SEDIMEN DI TELUK BENOA MENGGUNAKAN PEMODELAN NUMERIK
}

\author{
STUDY OF SEDIMENT TRANSPORT AT BENOA BAY USING NUMERICAL MODELLING \\ Herlambang Aulia Rachman ${ }^{\star}$ I Gede Hendrawan, I Dewa Nyoman Nurweda Putra \\ Program Studi IImu Kelautan, Fakultas Kelautan dan Perikanan, Universitas Udayana \\ Jalan Raya Kampus Unud, Bukit Jimbaran, Badung \\ ${ }^{*}$ Corresponding author e-mail: herlambangauliarachman@gmail.com
}

Submitted: 26 Agustus 2016 / Revised: 5 Oktober 2016 / Accepted: 29 Oktober 2016

DOI: http://dx.doi.org/10.21107/jk.v9i2.1617

\begin{abstract}
Benoa Bay is a semi-enclosed estuary located in the south of Bali. This area is became estuary for several rivers in Bali. The river is a source of material such as sediment transport stream that flowed into the sea. Sediment transport processes in Benoa Bay can be approximated by numerical modeling FVCOM (Finite Volume Coastal Ocean Model) to determine the distribution of sediments found in the bay area. Research carried out at Benoa Bay area in January 2016. The results of numerical models show that the process of sediment movement will follow the current pattern shape. The pattern of the movement of currents in the Benoa Bay will follow the pattern of tide where the current will flow lead into the bay at high tide and vice versa. Average flow velocity at the mouth reaches $0.8 \mathrm{~m} / \mathrm{s}$ at the time to the tide and $0.9 \mathrm{~m} / \mathrm{s}$ at the time towards low tide. Current speed will slow down when the condition of the highest and lowest tide that is only reached an average of about $0.3 \mathrm{~m} / \mathrm{s}$. The highest sediment concentrations occur in the section near the mouth of the river that reached $100 \mathrm{mg} / \mathrm{L}$ and the mouth of the bay, which reached $150 \mathrm{mg} / \mathrm{L}$. The high concentration of sediment at the mouth of the bay due to the erosion of the bottom waters due to the flow velocity is high. The results of the validation by tidal elevation models obtained root mean square error (RMSE) of 9:18 cm with a coefficient of determination $\left(R^{2}\right)$ reached 0.97 . For the comparison of model results with observational data in the form of sediment Total Suspended Solid has a level of correlation of 0.77 .
\end{abstract}

Keywords: Benoa Bay, Sediment, Numerical modelling

\section{ABSTRAK}

Teluk Benoa merupakan estuari semi tertutup yang terdapat di wilayah selatan Bali. Kawasan ini merupakan daerah yang menjadi muara bagi beberapa sungai besar yang terdapat di Bali. Sungai merupakan salah satu sumber aliran material seperti angkutan sedimen yang dialirkan menuju ke laut. Proses transpor sedimen di Teluk Benoa dapat didekati dengan pemodelan numerik FVCOM (Finite Volume Coastal Ocean Model) untuk mengetahui distribusi sedimen yang terdapat di daerah teluk. Penelitian dilakukan di seluruh area Teluk Benoa pada Januari 2016. Hasil model numerik menunjukkan bahwa proses pergerakan sedimen akan mengikuti bentuk pola arusnya. Pola pergerakan arus di Teluk Benoa akan mengikuti pola pasang surutnya dimana saat akan pasang pola arus akan mengarah ke dalam teluk dan sebaliknya. Kecepatan arus rata-rata pada bagian mulut mencapai $0.8 \mathrm{~m} / \mathrm{s}$ pada saat menuju pasang dan $0.9 \mathrm{~m} / \mathrm{s}$ pada saat menuju surut. Besar kecepatan arus akan mengalami perlambatan pada saat kondisi pasang tertinggi dan surut terendah yakni hanya mencapai rata-rata sekitar $0.3 \mathrm{~m} / \mathrm{s}$. Konsentrasi sedimen tertinggi terjadi pada bagian dekat muara sungai yang mencapai $100 \mathrm{mg} / \mathrm{L}$ dan mulut teluk yang mencapai 150 $\mathrm{mg} / \mathrm{L}$. Tingginya konsentrasi sedimen di mulut teluk diakibatkan adanya erosi pada bagian dasar perairan akibat kecepatan arus yang cukup tinggi. Hasil validasi elevasi pasang surut pada model didapatkan root mean square error (RMSE) sebesar $9.18 \mathrm{~cm}$ dengan koefisien determinasi $\left(\mathrm{R}^{2}\right)$ mencapai 0.97. Untuk perbandingan hasil model sedimen dengan data observasi berupa Total Suspended Solid memiliki tingkat korelasi sebesar 0.77

Kata Kunci: Teluk Benoa; Sedimen, Pemodelan numerik 


\section{PENDAHULUAN}

Sedimen adalah jenis polutan yang memiliki berat dan kemampuan tersuspensi paling tinggi diantara polutan lainnya. Sedimen yang berada di kawasan teluk atau daerah muara sungai pada umumnya berasal dari aktivitas pertanian yang berada di Daerah Aliran Sungai (DAS) yang digerakkan oleh proses hidrodinamika menuju muara sungai atau teluk (Sinha et al., 2007). Konsentrasi sedimen yang berada teluk akan mempengaruhi kondisi perairan terutama tingkat kekeruhan yang dapat mempengaruhi intensitas cahaya yang masuk ke kolom perairan. Proses transpor sedimen ke seluruh area teluk akan mempengaruhi tingkat konsentrasi sedimen yang berada masing-masing bagian dari teluk. Tingkat konsentrasi sedimen yang tinggi juga akan berpengaruh terhadap tingkat kadar oksigen terlarut yang terdapat di perairan (Talke et al., 2009). Proses penyebarannya ini akan dipengaruhi oleh kondisi arus yang terdapat di wilayah perairan tersebut.

Sedimentasi adalah masuknya muatan sedimen ke dalam suatu lingkungan perairan tertentu melalui media air dan diendapkan di dalam lingkungan tersebut (Rijn, 1993). Proses sedimentasi yang terjadi di suatu lokasi sangat dipengaruhi dinamika perairan pesisir. Kondisi hidrodinamika di wilayah pesisir akan menjadi penggerak utama dalam proses tansportasi sedimen yang berasal dari aliran sungai atau aktivitas yang terjadi di sekitar teluk. Pengamatan proses sedimentasi di Teluk secara in situ membutuhkan banyak waktu serta biaya yang tinggi. Beberapa metode telah diterapkan dalam upaya menekan waktu serta biaya dalam pengamatan distribusi sedimen diantaranya menggunakan teknologi remote sensing dan pemodelan numerik (Hendrawan dan Asai, 2008).

Teluk Benoa adalah kawasan pesisir yang terletak di wilayah selatan Pulau Bali. Lokasinya yang strategis membuat Teluk Benoa menjadi sangat potensial dalam mengembangkan pembangunan di Provinsi Bali. Wilayah Teluk Benoa merupakan pusat dari pengembangan pembangunan, zona pariwisata, dan terdapat pusat pelayanan Transporasi baik regional maupun internasional. Di sisi lain kawasan Teluk Benoa juga memiliki peranan penting terhadap lingkungan karena selain tempat bermuara beberapa sungai di Bali Selatan dan juga terdapat Taman Hutan Raya (TAHURA) Ngurah Rai. Beberapa sungai besar yang bermuara di Teluk Benoa antara lain Tukad Badung, Tukad Mati, dan Tukad Sama. Aliran ketiga sungai tersebut melewati daerah dengan aktivitas pertanian dan perkotaan yang tinggi seperti Badung dan Kota Denpasar.

Kondisi hidrodinamika di suatu kawasan teluk akan mempengaruhi kualitas perairan dan penyebaran polutan di dalamnya (Cunha et al., 2006). Secara umum proses hidrodinamika di Teluk Benoa dipengaruhi oleh arus pasang surut (Hendrawan et al. 2005). Arus pasang surut yang terdapat di Teluk Benoa masuk melalu bagian mulut teluk yang berada di antara Tanjung Benoa dan Pulau Serangan. Komponen arus pasang surut yang paling berpengaruh di Teluk Benoa adalah M2 (Hendrawan et al., 2005; Ardana dan Mahendra, 2008).

Pemodelan numerik adalah salah satu metode yang banyak digunakan dalam menentukan pola arus yang terdapat di laut. Telah banyak model hidrodinamika yang telah dikembangkan dalam menentukan pola arus laut diantaranya POM (Princeton Ocean Model) yang dikembangkan oleh Blumberg (1987) dan FVCOM (Finite Volume Coastal Ocean Model) yang dikembangkan oleh Chen et al (2006).

Proses hidrodinamika merupakan penggerak secara umum segala proses penyebaran polutan yang terdapat di laut baik itu limbah, sedimen, atau yang lainnya. Model Transpor sedimen telah sukses dilakukan secara 2 Dimensi dan menunjukkan mampu mensimulasikan proses trannsport sedimen yang terjadi di kawasan muara sungai atau teluk (Sinha et al., 2007; Hendrawan dan Asai, 2008). Keuntungan menggunakan pemodelan numerik dalam mensimulasikan proses transpor sedimen antara lain dapat menekan waktu dan biaya penelitian, serta dapat melakukan simulasi secara harian, bulanan, atau musiman. Simulasi menggunakan pemodelan numerik juga dapat diterapkan untuk melakukan forecasting, nowcasting, dan hindacasting (Kampf, 2009).

Studi tentang transpor sedimen dengan pemodelan numerik di Teluk Benoa sudah pernah dilakukan oleh Hendrawan dan Asai (2008) menggunakan metode Princeton 
Ocean Model (POM). Metode POM yang dikembangkan oleh Mellor dan Blumberg (1998) tersebut dalam pemecahan persamaan menggunakan metode finite difference dan horizontal grid. Metode ini memiliki kelemahan yakni kurangnya fleksibilitas secara geometri jika diterapkan pada garis pantai yang cukup kompleks seperti perairan Teluk Benoa. Salah satu metode pemodelan numerik yang memiliki fleksibilitas secara geometri adalah metode Finite Volume Coastal Ocean Model (FVCOM). Studi transpor sedimen dengan menggunakan metode FVCOM sebelumnya pernah dilakukan di Teluk Deep, Hongkong. Metode ini dalam proses diskritisasinya menggunakan kombinasi antara metode pendekatan finite difference dan finite element yang memakai unstructured triangular grid untuk memberikan fleksibilitas secara geometri terutama pada daerah dengan garis pantai yang kompleks (Chen. et al., 2006). Dengan menggunakan metode tersebut diharapkan akan memberikan hasil yang lebih akurat dalam aplikasi model numerik untuk perairan Teluk Benoa yang memiliki pola garis pantai yang kompleks. Oleh karena itu perlu dilakukan penelitian tentang pola transpor sedimen menggunakan metode Finite-volume yang dapat mencakup kompleksitas geometri garis pesisir yang terdapat di Teluk Benoa.

Dalam perkembangan ilmu teknologi rekayasa untuk menganalisa struktur banyak yang menggunakan Metode Elemen Hingga diantaranya dengan melakukan simulasi struktur dudukan mesin M/E kemudian didiskritisi kedalam bentuk-bentuk elemen yang terhubung dalam beberapa nodal. Metode Elemen Hingga digunakan untuk mengetahui berapa tegangan maksimum yang terjadi, baik tegangan geser maupun tegangan lentur struktur kapal dengan memperhatikan batas tegangan pada struktur dengan memasukan nilai faktor keamanan, dengan hasil tegangan yang terjadi tidak boleh melebihi batas yang diijinkan. Sebagai upaya teknis untuk memastikan analisa kekuatan dalam perancangan, bahwa kondisi-kondisi struktur kapal penangkap ikan 30 GT berbahan fiberglass dalam tahap ship design cukup aman dari adanya resiko yang ditimbulkan oleh beban statis maupun dinamis yang menimbulkan bending moment pada kapal. Dimana dapat dilakukan dengan memberikan perhitungan di berbagai kondisi pembebanan, diantaranya pembebanan dasar, pembebanan sisi, pembebanan geladak, pembebanan akibat adanya muatan dan lain-lain.

\section{MATERI DAN METODE}

Penelitian dilakukan di kawasan Teluk Benoa, Bali pada periode Januari 2016. Pengambilan data Total Suspended Solids (TSS) dan debit sungai dilakukan pada setiap muara sungai yang kemudian dijadikan sebagai input model. Data sebagai input dilakukan setiap minggu selama waktu penelitian. Metode yang digunakan dalam pengujian sampel air dilakukan berdasarkan prosedur Standar Nasional Indonesia (SNI) No 06-6989.3-2004 tentang cara uji padatan tersuspensi secara gravimetri. Untuk lokasi pengambilan data input dan validasi data ditunjukkan pada gambar 1 . Sungai merupakan point source yang menyumbang sedimen paling banyak di perairan, terutama perairan Teluk yang merupakan daerah yang menjadi muara sungai (Sinha et al., 2010).

Model yang digunakan dalam membuat simulasi transport sedimen ini adalah model 3-D dengan unstructured grid, free-surface, primitve equation yang biasa disebut Finite Volume Coastal Ocean Model (FVCOM) (Chen et al, 2006). Berbeda dengan bentuk diferensial yang digunakan dalam finitedifference dan finite-element, diskritisasi yang dilakukan FVCOM dilakukan secara berbeda dengan menggabungkan kedua metode tersebut. Dalam persamaan ini persamaan integral dapat diselesiakan secara numerik dengan perhitungan fluks (metode finite-difference) dan terdapat triangular grid dengan ukuran yang dapat disesuaikan sehingga memberikan geometri garis pantai yang lebih fleksibel (metode finite-element). Untuk koordinat secara vertical dilakukan transformasi ke dalam bentuk sigma koordinat $(\sigma)$ sehingga memberikan bentuk vertical layer akan mengikuti bentuk dari topografi dasar perairan. Bentuk transformasi persamaan pembangun dalam model $\sigma$ koordinat adalah sebagai persamaan 1-6. 
$\frac{\partial \zeta}{\partial t}+\frac{\partial D u}{\partial x}+\frac{\partial D V}{\partial y}+\frac{\partial \omega}{\partial \sigma}=0$

$\frac{\partial u D}{\partial t}+\frac{\partial u^{2} D}{\partial x}+\frac{\partial u v D}{\partial y}+\frac{\partial u \omega}{\partial \sigma}-f v D=-g D \frac{\partial \zeta}{\partial x}-\frac{g D}{\rho_{0}}\left[\frac{\partial}{\partial x}\left(D \int_{\sigma}^{0} \rho d \sigma\right)+\sigma \rho \frac{\partial D}{\partial x}\right]+\frac{1}{D} \frac{\partial}{\partial \sigma}\left(K_{m} \frac{\partial u}{\partial \sigma}\right)+D F_{x}$

$\frac{\partial v D}{\partial t}+\frac{\partial v^{2} D}{\partial x}+\frac{\partial u v D}{\partial y}+\frac{\partial v \omega}{\partial \sigma}-f u D=-g D \frac{\partial \zeta}{\partial y}-\frac{g D}{\rho_{0}}\left[\frac{\partial}{\partial y}\left(D \int_{\sigma}^{0} \rho d \sigma\right)+\sigma \rho \frac{\partial D}{\partial y}\right]+\frac{1}{D} \frac{\partial}{\partial \sigma}\left(K_{m} \frac{\partial v}{\partial \sigma}\right)+D F_{y}$

$\frac{\partial T D}{\partial t}+\frac{\partial T u D}{\partial x}+\frac{\partial T v D}{\partial y}+\frac{\partial T \omega}{\partial \sigma}=\frac{1}{D} \frac{\partial}{\partial \sigma}\left(K_{h} \frac{\partial T}{\partial \sigma}\right)+D H+D F_{T}$

$\frac{\partial S D}{\partial t}+\frac{\partial S u D}{\partial x}+\frac{\partial S v D}{\partial y}+\frac{\partial S \omega}{\partial \sigma}=\frac{1}{D} \frac{\partial}{\partial \sigma}\left(K_{h} \frac{\partial S}{\partial \sigma}\right)+D F_{S}$

$\rho=\rho(T, S)$

PETA PENGAMBILAN DATA VALIDASI HASIL MODEL

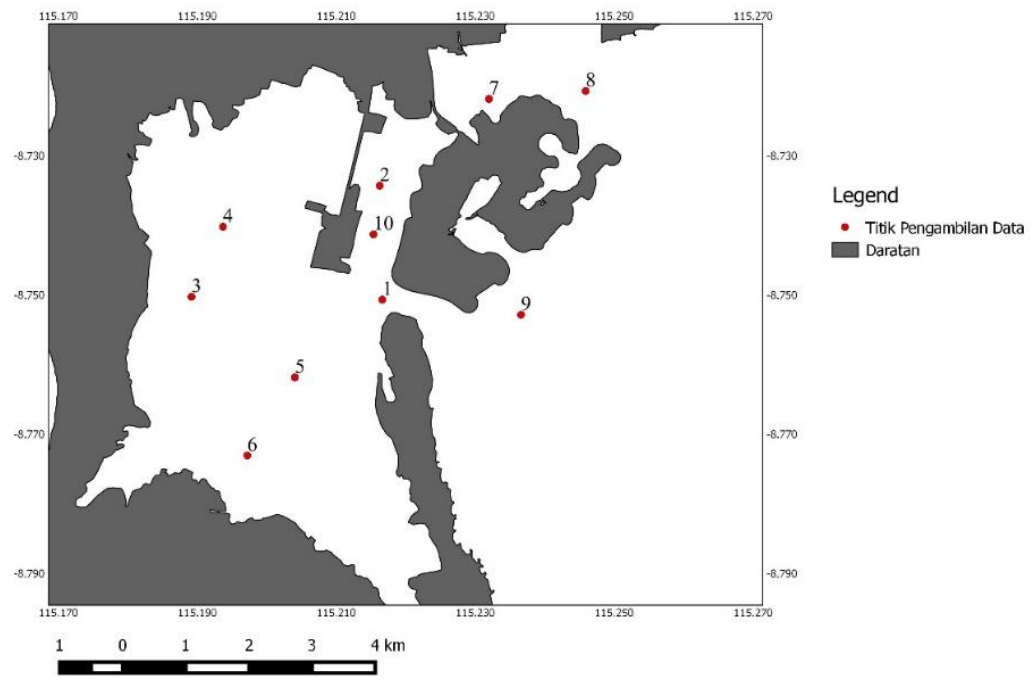

Gambar 1. Peta lokasi penelitian dan pengambilan sampel in-situ

\section{Model Transpor Sedimen}

Pada model Transpor sedimen yang terdapat dalam FVCOM mencakup model untuk Transpor bed load dan suspended load. Dalam implementasi dari model tersebut load

$\frac{\partial C_{i}}{\partial t}+\frac{\partial u C_{i}}{\partial x}+\frac{\partial v C_{i}}{\partial y}+\frac{\partial\left(w-w_{i}\right) C_{i}}{\partial z}=\frac{\partial}{\partial x}\left(A_{u} \frac{\partial C_{i}}{\partial x}\right)+\frac{\partial}{\partial y}\left(A_{u} \frac{\partial C_{i}}{\partial y}\right)+\frac{\partial}{\partial z}\left(K_{h} \frac{\partial C_{i}}{\partial z}\right)$

dimana $\mathrm{C}_{\mathrm{i}}$ adalah nilai konsentrasi dari sedimen yang tersuspensi, Ah adalah nilai viskositas eddy secara horizontal, dan $\mathrm{Kh}$ adalah viskositas eddy secara vertikal. Sedangkan untuk $w_{i}$ adalah nilai dari Settling Velocity (kecepatan mengendap) yang disesuaikan dengan input jenis sedimen yang sedimen dihitung secara terpisah dan kemudian ditambahkan untuk menghasilkan total load. Model untuk menghitung nilai suspended load adalah pendekatan berbasis konsentrasi dengan persamaan 7 . 
Untuk area dasar, nilai sediment flux memiliki perbedaan antara deposisi dan erosi. Untuk nilai deposisi sedimen digunakan persamaan sebagai berikut :

$K_{h} \frac{\partial C_{i}}{\partial z}=E_{i}-D_{i}, z=\zeta$

dan untuk erotion rate dapat dihitung dengan persamaan sebagai berikut :

$E_{i}=\Delta t Q_{i}\left(1-P_{b}\right) F_{b i}\left(\frac{\tau_{b}}{\tau_{c i}}-1\right)$

dimana $Q_{i}$ adalah erosion flux, $P_{b}$ adalah porosity yang terdapat di dasar perairan, $\mathrm{F}_{\mathrm{bi}}$ adalah fraction dari sedimen di dasar, $\tau_{b}$ adalah tekanan bottom shear stress, dan $\tau_{c i}$ adalah nilai dari critical shear stress dari sediment tersebut.

\section{HASIL DAN PEMBAHASAN}

\section{Verifikasi Elevasi Permukaan Air}

Verifikasi data lapangan perlu dilakukan dalam suatu pemodelaan numerik agar dapat diketahui sejauh mana penyimpangan dari hasil simulasi yang telah dilakukan. Sebuah model dapat dikatakan valid jika hasil simulasinya memiliki pola yang konsisten dengan data lapangan. Dalam model ini data elevasi muka air akan diverifikasi dengan data lapangan milik BMKG. Verifikasi dilakukan dengan membandingkan data elevasi hasil elevasi pasang surut model dengan data pengamatan pada stasiun pasut milik BMKG yang terdapat di Teluk Benoa pada periode Januari 2016.

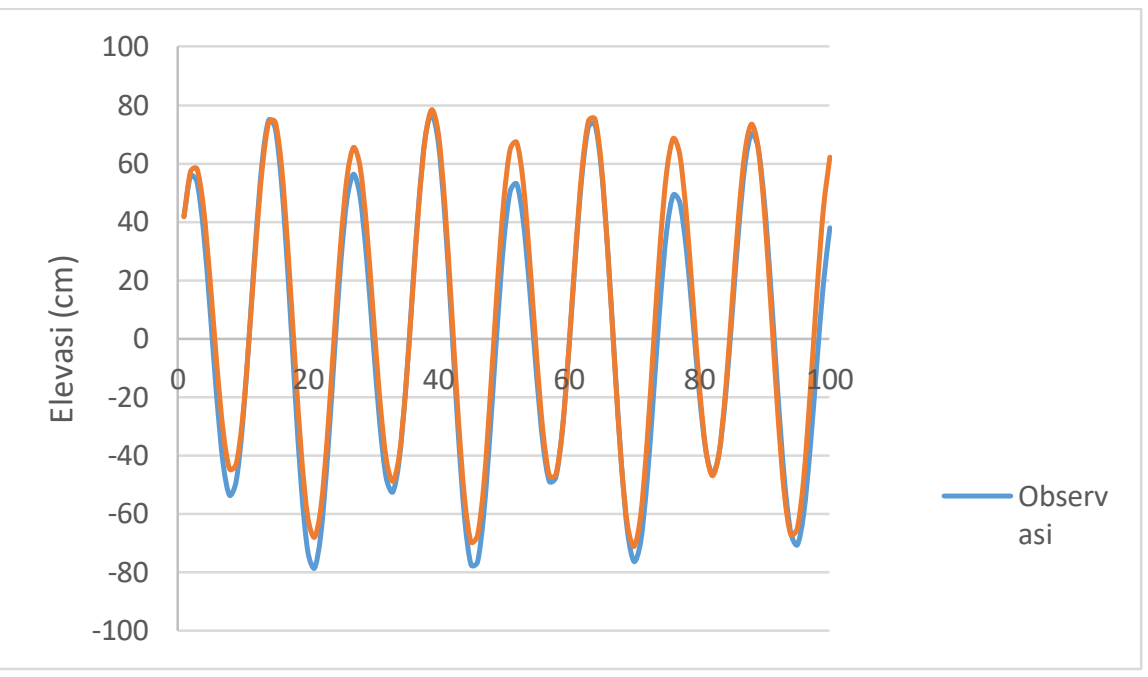

Gambar 1. Grafik perbandingan Elevasi Hasil Model dengan Observasi Lapangan

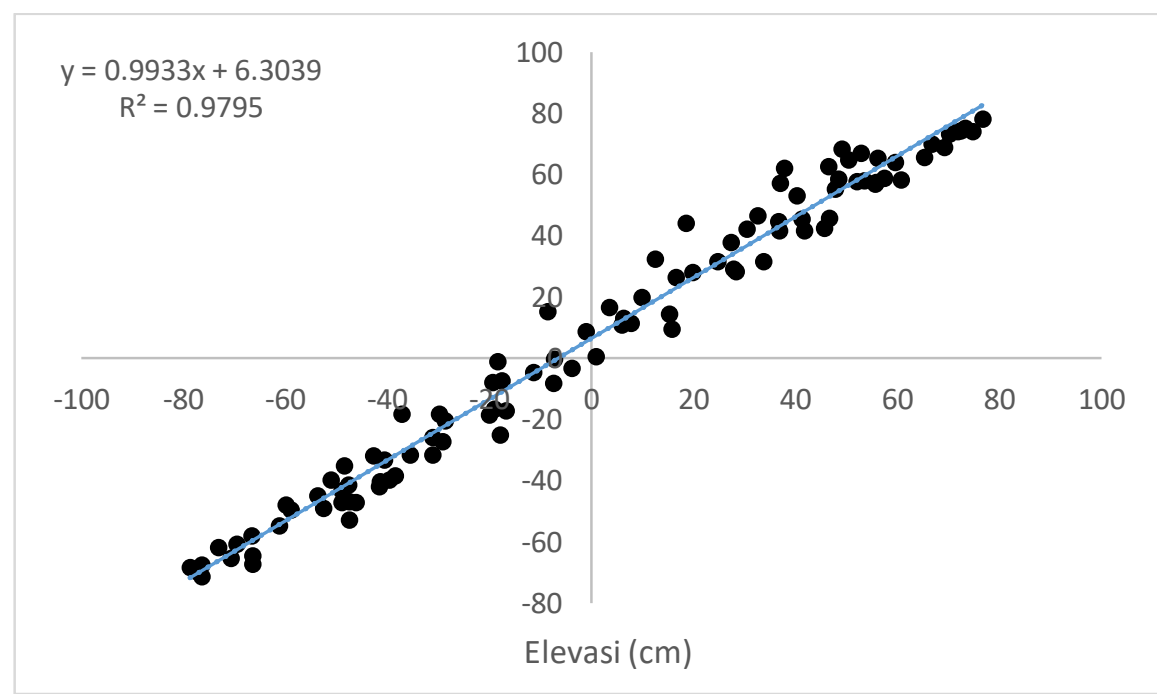

Gambar 2. Grafik Scatter Ploy Elevasi Muka Air Hasil Model dan Observasi 
Berdasarkan Gambar 1 dan 2 menunjukkan bahwa secara umum data elevasi hasil model dan data lapangan memiliki pola yang sama. Perhitungan secara kuantitatif menggunakan rumus Root Mean Square Error (RMSE), perbedaan anatar hasi model dan observasi memiki error hanya sebesar $9.18 \mathrm{~cm}$. Dari gambar 4.1b menunjukkan bahwa hasil scatter plot antara hasil model dan observasi yang didekati dengan garis linear yang memiliki nilai koefisien $\mathrm{R}^{2}$ sebesar 0.97 yang artinya memiliki pola yang mirip antara keduanya.

\section{Validasi Model Transport Sedimen}

Pola sebaran konsentrasi sedimen hasil simulasi numerik telah divalidasi dengan data lapangan. Validasi dilakukan dengan membandingkan data hasil model dengan data lapangan berupa konsentrasi Total Suspended Solid (TSS). Hasil validasi menunjukkan pola yang hampir sama antara konsentrasi sedimen hasil validasi dan Total Suspended Solid dengan korelasi yang cukup baik yakni mencapai 0.77. Perbedaan jumlah konsentrasi tersebut disebabkan karena untuk konsentrasi TSS yang dihitung merupakan total dari semua fraksi suspended solid yang terdapat di perairan seperti sedimen, dissolve organic meter, bahan organik, plankton dan lain sebagainya. Sedangkan untuk parameter yang disimulasikan dalam model hanya meliputi sedimen lumpur yang merupakan material anorganik.

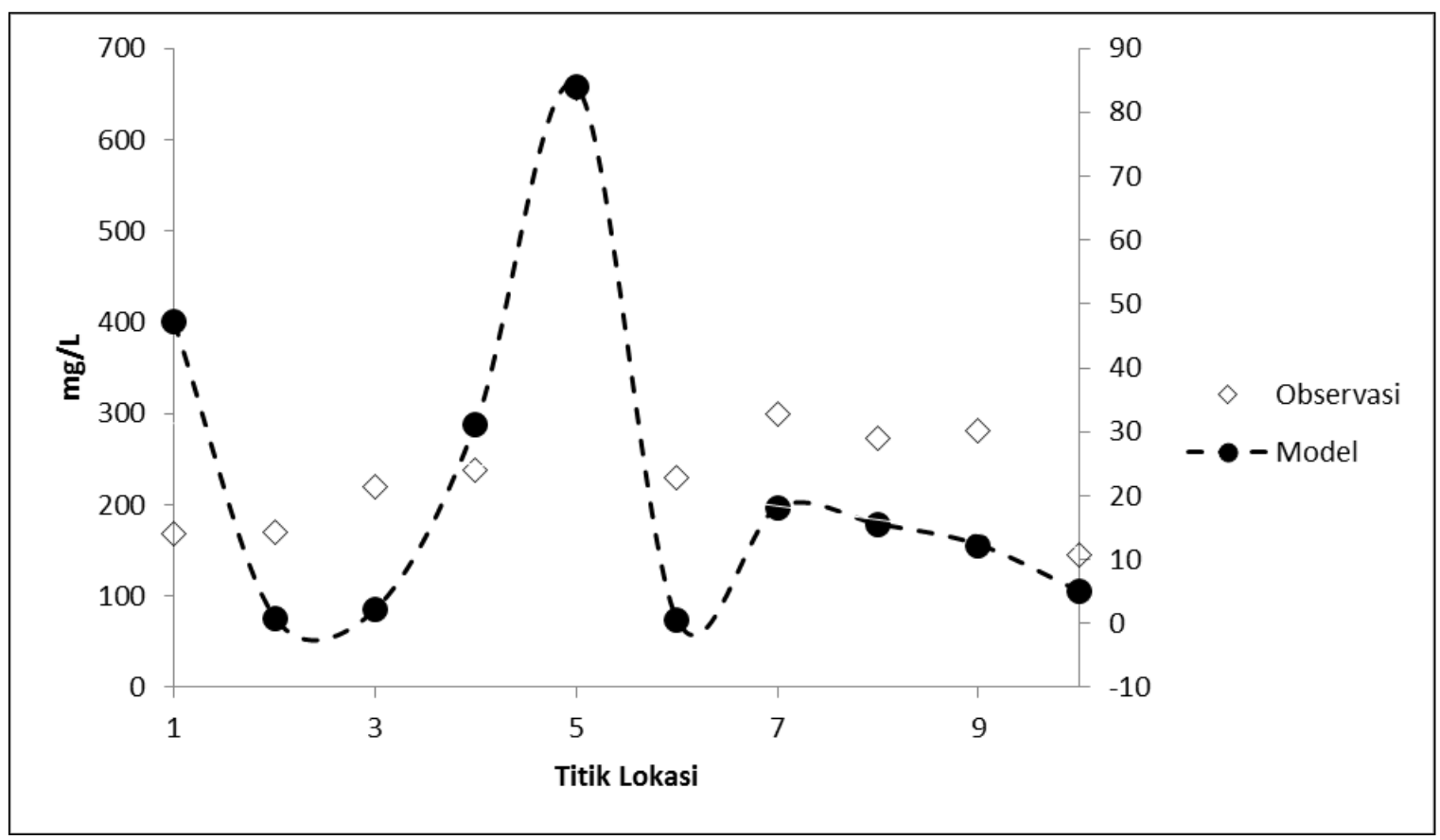

Gambar 3. Grafik Perbandingan konsentrasi TSS dan konsentrasi sedimen hasil model.

\section{Pola Pergerakan Arus}

Simulasi hasil model ini merupakan pola arus yang terdapat di Teluk Benoa yang dipengaruhi oleh adanya perbedaan tinggi muka air di open boundary (batas terbuka) yang terdapat di batas terbuka di bagian luar wilayah Teluk. Adanya proses naik turunnya muka air secara vertikal secara periodik akan mengahsilkan gaya yang akan membangkitkan pola arus. Simulasi model pola arus ini dilakukan pada saat kondisi pasang (flood tide) dan surut (ebb tide). Dari kedua kondisi tersebut terdapat dua tinjauan yang dilakukan berdasarkan elevasi muka air, pada saat menuju pasang atau surut dan pasang tertinggi atau surut terendah 


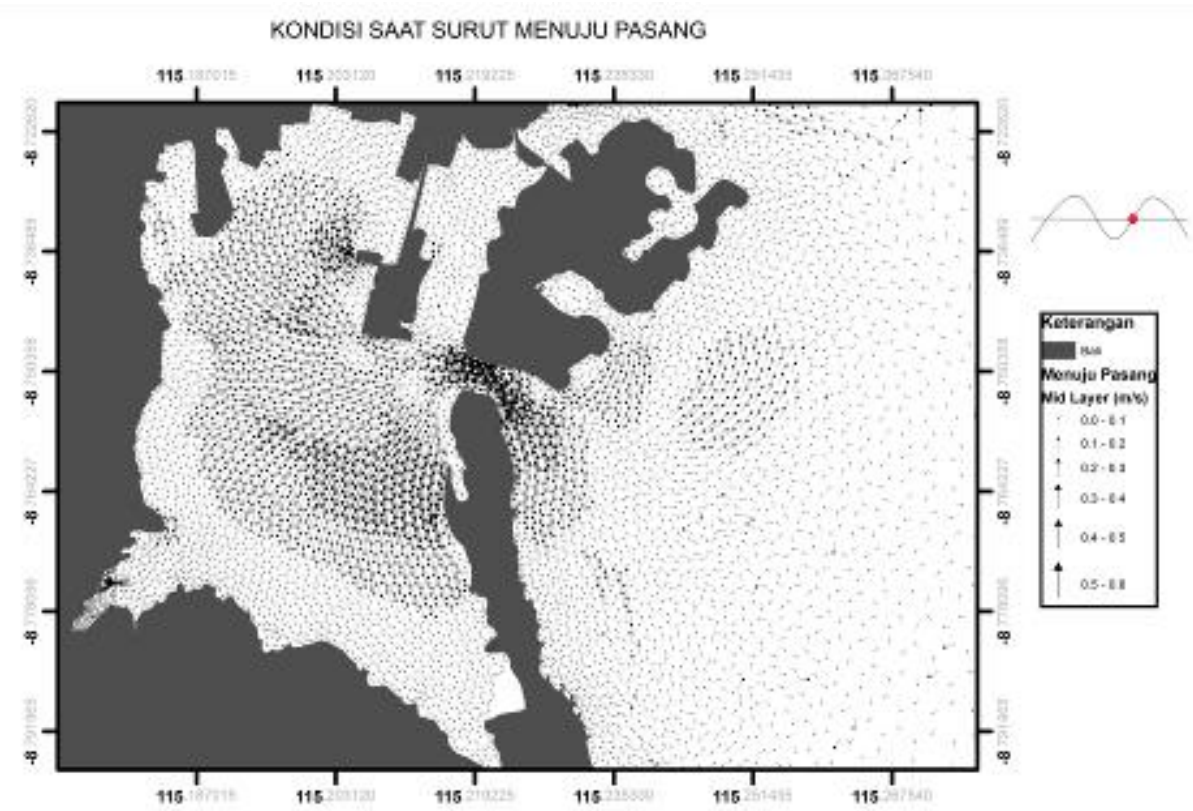

(a)

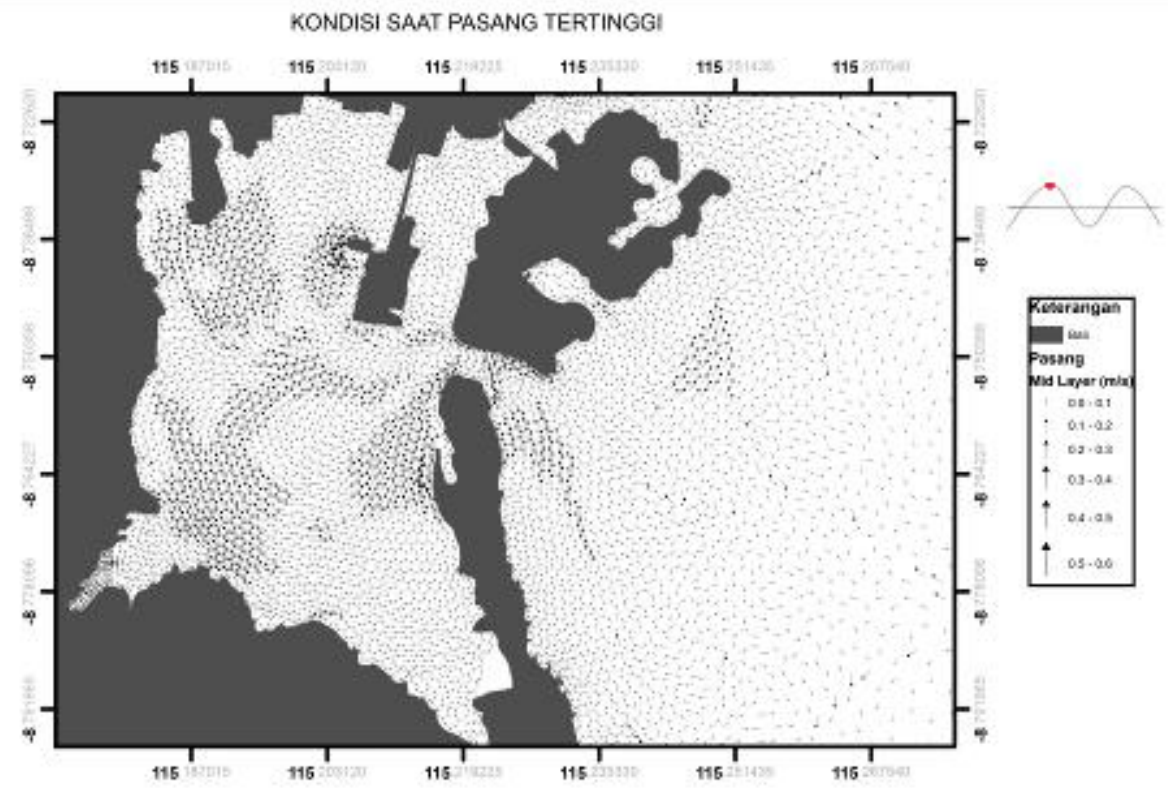

(b)

Gambar 4. (a) Kondisi pola arus pada saat menuju pasang (b) kondisi pola arus pada saat menuju surut

Pada saat air mulai pasang (gambar 4a) pergerakan massa air masuk ke dalam bagian teluk melalui mulut teluk yang terdapat diantara pulau serangan dan wilayah tanjung benoa. Pada saat tersebut kecepatan arus permukaan di bagian mulut teluk mencapai nilai $0.6 \mathrm{~m} / \mathrm{s}$. Kondisi tersebut dikarenakan ukuran lebar mulut teluk yang relatif cukup kecil sehingga membuat kecepatan arus yang masuk cukup tinggi. Pada bagian dalam dan wilayah luar teluk, arus yang dihasilkan cenderung lebih rendah daripada yang terdapat di bagian mulut teluk.
Hal ini dikarenakan luasan daerah tersebut lebih lebar serta untuk bagian dalam teluk arah arus akan di belokkan dengan adanya close boundary yakni wilayah daratan. Pada saat kondisi pasang tertinggi (gambar 4b), rata-rata nilai besaran kecepatan arus semakin menurun dibandingkan dengan kondisi menuju pasang. Pada bagian dalam Teluk, pergerakan air cenderung memutar dan membentuk eddy akibat adanya boundary yang membatasi area teluk. Besar kecepatan arus di area dalam teluk berkisar antara $0-0.1 \mathrm{~m} / \mathrm{s}$. Sedangkan untuk bagian 
mulut teluk, pergerakan air cenderung bergerak semakin melemah dengan kecepatan maksimal mencapai $0.3 \mathrm{~m} / \mathrm{s}$.

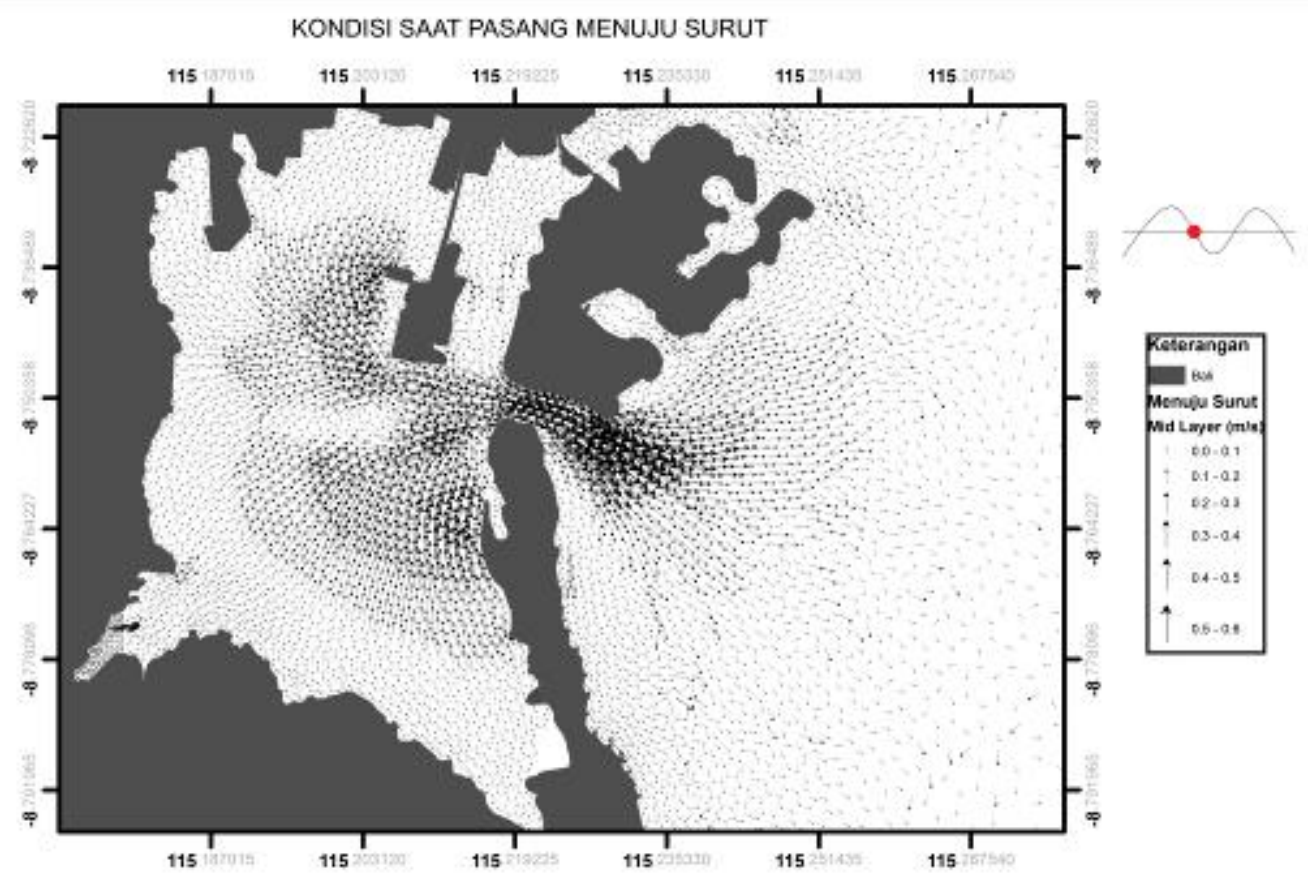

(a)

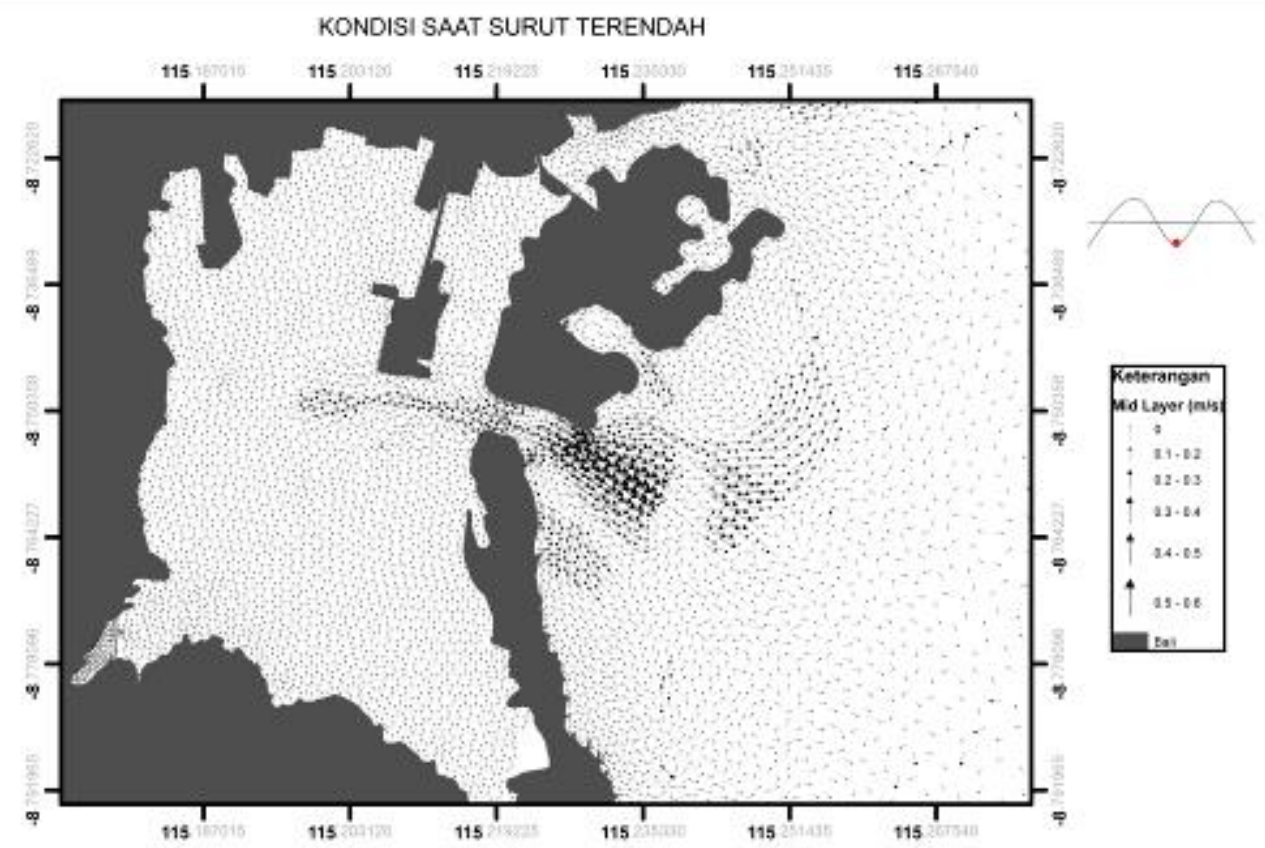

(b)

Gambar 5. (a) Kondisi pola arus pada saat menuju surut (b) kondisi pola arus pada saat surut terendah

Pada saat kondisi menuju surut (gambar 5a), pola pergerakan arus mengarah keluar melalui area mulut teluk. Kecepatan arus yang mengarah keluar pada bagian permukaan mencapai $0.7 \mathrm{~m} / \mathrm{s}$. Kondisi mulut teluk yang relatif lebih sempit serta besar volume air yang bergerak menuju keluar teluk pada saat surut membuat kecepatan arus di area ini cukup tinggi. Pada bagian dalam teluk pergerakan air cenderung bergerak 
menuju keluar teluk benoa. Kondisi surut terendah memiliki kondisi yang hampir sama saat pasang tertinggi dimana rata-rata kecepatan arus cukup rendah. Kontur batimetri yang cukup dangkal membuat bagian dalam teluk pada saat surut terndah tidak terendam air sehingga akan terlihat seperti daratan. Dalam simulasi model bagian-bagian yang tidak terendam air tersebut akan di hitung sebagai vektor nol atau memiliki kecepatan sama dengan nol. Pola pergerakan arus hanya berada pada bagian mulut teluk yang merupakan alur pelayaran sehingga kontur batimetri lebih dalam daripada bagian dalam teluk Pola pergerakan arus pada mulut teluk akan bergerak cenderung keluar dengan kecepatan mencapai $0.3 \mathrm{~m} / \mathrm{s}$. Sementara untuk bagian luar teluk, kecepatan arus akan semakin menurun dibandingkan pada saat kondisi pasang menuju surut.

\section{Pola Transport Sedimen}

Hasil pemodelan numerik untuk proses transpor sedimen merupakan pola sebaran konsentrasi sedimen pada setiap layer kedalaman di saat pasang, surut, dan kondisi mean sea level (menuju pasang/surut). Dalam model simulasi transport sedimen, sumber sedimen diasumsikan berada pada setiap sungai yang bermuara di Teluk Benoa antara lain Tukad Loloan, Tukad Mati, dan Tukad Buji. Dari setiap sungai tersebut parameter yang diberikan adalah nilai debit sungai dan konsentrasi nilai TSS.

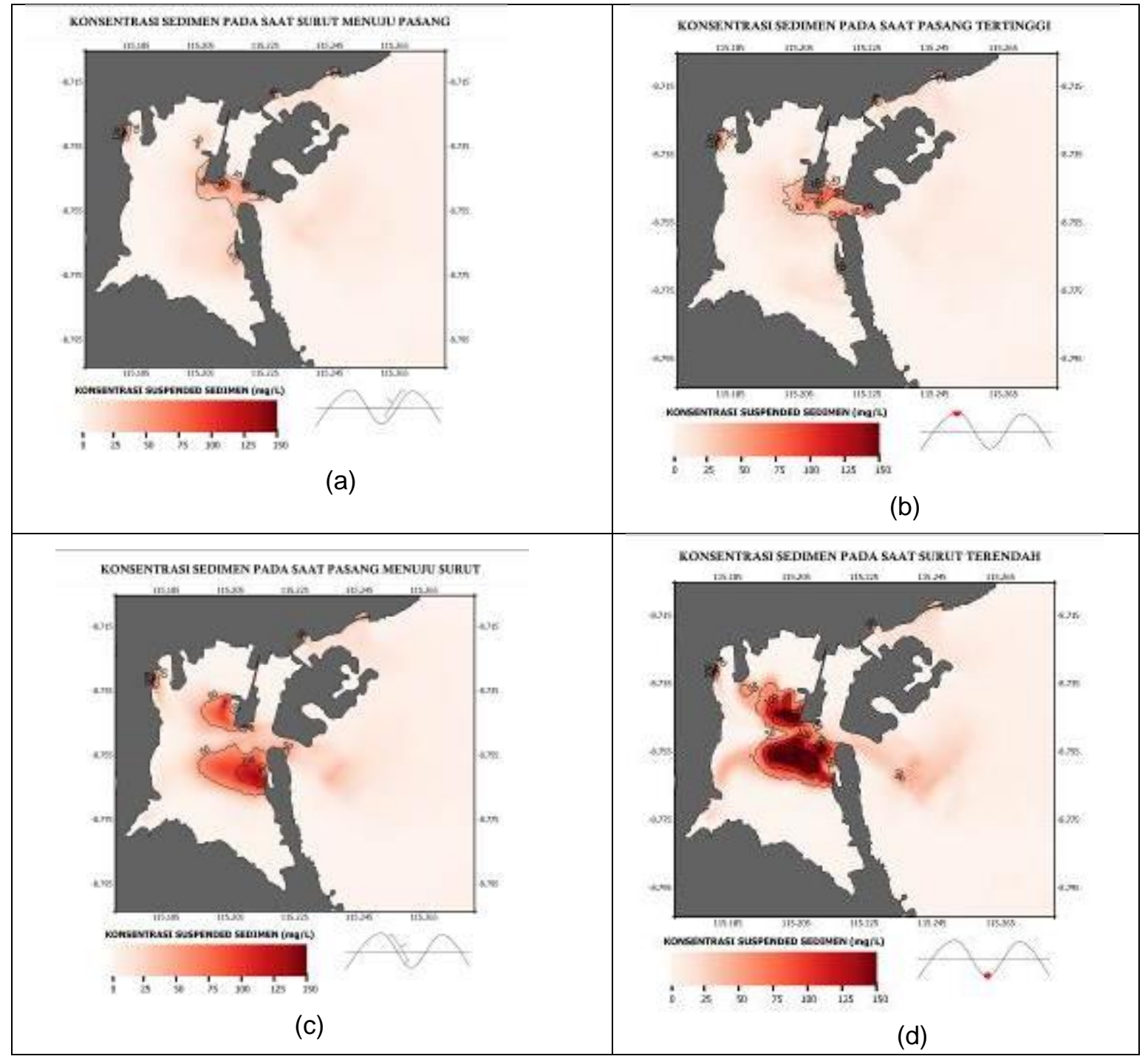

Gambar 6. Pola konsentrasi sedimen (a) kondisi surut menuju pasang (b) kondisi pasang tertinggi (c) kondisi pasang menuju surut (d) kondisi surut terendah 
Pola transpor sedimen pada saat kondisi menuju pasang memiliki konsentrasi cenderung rendah. Hal tersebut diakibatkan karena pada saat kondisi menuju pasang pola pergerakan arus yang membawa massa air akan bergerak masuk menuju ke dalam teluk (gambar 4a). Kondisi tersebut akan membuat konsentrasi sedimen yang terdapat didalam teluk akan mengalami pengenceran sehingga menurunkan nilai konsentrasi sedimen. Pada saat kondisi surut menuju pasang nilai konsentrasi sedimen tertinggi berada pada daerah dekat muara sungai sebesar $120 \mathrm{mg} / \mathrm{L}$ serta pada bagian mulut teluk dengan kosentrasi mencapai $60 \mathrm{mg} / \mathrm{L}$. Muatan sedimen yang tinggi pada daerah dekat mulut teluk diduga akibat adanya arus yang cukup tinggi sehingga membuat muatan sedimen yang berada pada bagian dasar teluk akan teraduk dan menaikkan konsentrasi sedimen di perairan.

Pada saat kondisi pasang tertinggi, pola konsentrasi sebaran sedimen akan cenderung rendah. Hal tersebut diakibatkan adanya masukan air laut yang mengakibatkan terjadinya pengenceran terhadap konsentrasi sedimen yang terdapat di dalam teluk. Konsentrasi sedimen tertinggi pada saat pasang terdapat pada bagian muara sungai dan pada mulut teluk. Pada bagian muara sungai nilai konsentrasi sedimen mencapai $120 \mathrm{mg} / \mathrm{L}$ pada ketiga bagian sungai tersebut. Sementara pada bagian mulut teluk nilai konsentrasi sedimen mencapai nilai $60 \mathrm{mg} / \mathrm{L}$. Tingginya konsentrasi di bagian muara sungai dikarenakan sungai merupakan point source. Tingginya konsentrasi sedimen di mulut teluk diduga akibat adanya erosi sedimen yang terjadi di dasar perairan. Nilai konsentrasi tersebut relatif lebih tinggi daripada kondisi menuju pasang di kolom perairan. Hal tersebut karena kecepatan arus yang semakin melemah sehingga sedimen akan mulai tenggelam menuju dasar perairan karena memiliki densitas lebih tinggi daripada air laut.

Pada saat kondisi menuju surut, pola arus akan cenderung mengarah keluar bagian Teluk Benoa dengan kecepatan rata-rata mencapai $0.6 \mathrm{~m} / \mathrm{s}$ (Gambar 5a). Pola pergerakan sedimen pada saat menuju surut juga akan mengikuti pola dari arah arus dimana sedimen akan bergerak menuju ke mulut teluk. Pada saat pergerakan arus menuju keluar teluk membuat pada bagian dekat mulut pada dekat pelabuhan dan pesisir barat tanjung benoa mengalami penumpukan konsentrasi sedimen. Hal tersebut diduga karena tingginya kecepatan arus yang bergerak keluar teluk yang bergesekan dengan dasar perairan yang relatif dangkal dengan mulut teluk. Konsentrasi sedimen yang tinggi juga berada pada daerah dekat muara sungai yang menjadi point source untuk sedimen di perairan. Nilai konsentrasi sedimen pada bagian mulut teluk relatif cukup tinggi yakni mencapai $80 \mathrm{mg} / \mathrm{L}$. Sementara untuk muara sungai nilai konsentrasi sedimen mencapai $120 \mathrm{mg} / \mathrm{L}$ dikarenakan sungai merupakan point source dari model sedimen.

Pada saat kondisi surut terendah pergerakan air akan bergerak menuju keluar area teluk. Kecepatan arus pada kondisi surut terendah akan mengalami penurunan dari kondisi menuju surut karena gaya pembangkit arus yang berupa pasut akan semakin menurun. Penurunan kecepatan arus tersebut akan berdampak pada arah pergerakan arus dimana pada saat menuju surut, arus akan bergerak menuju langsung ke mulut teluk akan berubah menuju titik tengah dari mulut teluk. Melemahnya kecepatan arus akan membuat sedimen yang cukup tinggi pada saat menuju surut akan tertahan di bagian dalam di dekat mulut teluk. Konsentrasi sedimen pada saat surut terendah mencapai $150 \mathrm{mg} / \mathrm{L}$ dan terpusat pada bagian dekat mulut teluk.

\section{KESIMPULAN DAN SARAN}

Pola transpor sedimen yang terdapat di teluk benoa akan mengikuti bentuk dari pola arusnya. Kecepatan arus yang cukup tinggi pada daerah teluk diduga membuat gesekan terhadap lapisan sedimen yang terdapat di dasar sehingga membuat sedimen di daerah mulut teluk cukup tinggi yang mencapai 100 $\mathrm{mg} / \mathrm{L}$. Konsentrasi sedimen tertinggi berada pada bagian dekat muara sungai dengan konsentrasi mencapai $150 \mathrm{mg} / \mathrm{L}$. Perbandingan konsentrasi sedimen hasil model dan observasi memiliki pola yang hampir sama dengan nilai koefisien korelasi sebesar 0.77 .

\section{UCAPAN TERIMA KASIH}

Penulis mengucapkan terima kasih kepada Fakultas Kelautan dan Perikanan yang memberikan fasilitas Laboratorium Komputasi sebagai tempat dalam menjalankan penelitian ini. Ucapan terima 
kasih juga disampaikan kepada seluruh tim Laboratorium Komputasi yang turut membantu kelancaran dalam penelitian ini.

\section{DAFTAR PUSTAKA}

Ardana, K., \& Mahendra, M. S. (2009). Study of pollutant distribution in Benoa Bay using numerical simulation and satellite data. Ecotrophic, 3(2), 81-86

Blumberg, A. F., \& Mellor, G. L. (1987). A Description of a three-dimensional coastal ocean circulation model. In Three-dimensional Coastal Ocean Model, N.H. Heaps, ed., Coastal. Estuari. Sci., 1-6.

Chen, C., Beardsley, Cowles, R. C., \& Geoffrey. (2006). An Unstructured Grid, Finite Volume Coastal Ocean Model (FVCOM) User Manual.

Hendrawan, I. G., \& Asai, K. (2008). Study of Suspended Sediment Distribution Using Numerical Model and Satellite
Data in Benoa Bay-Bali, Indonesia. Department of Civil and Environmental Engineering, Yamaguchi University.

Kampf, J. (2009). Ocean Modelling for Beginners. Springer Heidelberg Dordrecht London New York

Rijn, L. C. V. (1990). Principles of Sediment Transport in Rivers, Estuaries and Coastal Seas. Aqua Publication. University of Utrecht Department of Physical Geography. Amsterdam

Sinha, P. C., Jena, G. K., Jain, I. R., Husain, A. D., \& Lokman, M. (2010). Numerical of Tidal Circulation and Sediment Transport in the Gulf of Khambhat and Narmada Estuary, West Coast of India. Pertanika J. Sci and Technol. University Putra Malaysia Press.

Talke, S. A., \& de Swart, H. E. (2009). An Idealized Model and Systematic Process Study of Oxygend Depletion in Highly Turbid Estuaries. Estuaries and Coast 32, 602-620. 